\title{
ARE TRUSTEES OF THE ESTATES OF OWNERS OF SECTIONAL TITLE UNITS NOT FULLY COVERED BY SECTION 89 OF THE INSOLVENCY ACT?
}

Kgosi Mokgoetsi

$B A$ Hons LLB LLM Certificate in Risk, Compliance and Governance

Associate Lecturer, School of Law, University of the Witwatersrand

Clement Marumoagae

LLB LLM LLM PhD Diploma in Insolvency Law and Practice

Associate Professor, School of Law, University of the Witwatersrand

\section{SUMMARY}

This article highlights differential treatment of trustees when they make application for the clearance certificates, they need to register a transfer of immovable property. It illustrates that trustees of the estates of insolvent owners of sectional titles scheme units who apply for clearance certificates from bodies corporate do not enjoy the benefits provided by section 89 of the Insolvency Act. In comparison, such protection is provided to trustees when the estate is that of an insolvent owner of a property indebted to a municipality. The article argues that the Supreme Court of Appeal (SCA) in various judgments has incorrectly interpreted the law by not fully subjecting bodies corporate to section 89 of the Insolvency Act. The article argues that the time limits regarding protection from payment of charges, fees and levies applicable to trustees in relation to municipalities should be equally applicable to bodies corporate. The article recommends that the legislature must step in and clarify its intention by amending the provisions in the Sectional Titles Act that make provision for bodies corporate to issue clearance certificates. 


\section{$1 \quad$ INTRODUCTION}

Sectional title denotes separate ownership of individual sections, commonly referred to as units, within a complex or development. ${ }^{1}$ Ownership within a sectional titles scheme comprises individual ownership of a particular unit, joint ownership of certain parts of the complex or development, and membership of the body corporate. ${ }^{2}$ In terms of section 2(c) of the Sectional Titles Act $^{3}$ (STA), the owners of different units within a sectional titles scheme own the complex or development, subject to a sectional title in undivided shares. In order to ensure that sectional titles are managed and administered efficiently, the legislature promulgated the Sectional Titles Schemes Management Act ${ }^{4}$ (STSMA). In terms of the Preamble to the STSMA, the Act provides for the establishment of bodies corporate that are legislatively entrusted with the management and regulation of the complex or development subject to the sectional title and the units contained therein. Owners of all the individual units within the sectional title are members of these bodies corporate; ${ }^{5}$ individual membership ceases when an owner ceases to be the owner of any of the units. ${ }^{6}$ This enables bodies corporate to have perpetual succession because membership changes as ownership within the sectional title units changes. ${ }^{7}$ Once constituted, a body corporate is a juristic person that can sue or be sued in its name regarding any contract that it has entered into, any damage to the common property, matters relating to the land or building for which owners are jointly liable, conduct or omission relating to its duties, and claims against the developer. ${ }^{8}$

In terms of section 7 of the STSMA, the powers and functions of the body corporate must be performed and exercised by the trustees of the body corporate. Both the trustees and the owners of units within a sectional titles scheme have duties that they need to perform in order for it to run efficiently. Probably the most important are the trustees' duty to collect levies, which are the lifeblood of sectional titles schemes, and the owners' duty to make payment. Unfortunately, some unit owners are often unable to honour their obligations to make the required periodic payments, resulting in substantial levy arrears. At times, defaulting owners run into financial difficulties to the extent that they do not have enough money or movable property to make payment, making debt collection procedures futile. It often transpires that the only substantial property in which defaulting owners have a financial interest

1 In terms of s 2(a) of the Sectional Titles Act 95 of 1986, "[a] building or buildings comprised in a scheme and the land on which such building or buildings is or are situated, may be divided into sections and common property in accordance with the provisions of this Act." See also Bartlett "Pro's and Con's of Sectional Title Ownership" (19 June 2012) https://www.phinc.co.za/NewsResources/NewsArticle.aspx?ArticlelD=291 (accessed 202002-20).

2 See s 36(1) and (2) of the STA. See also Booysen "A Critical Analysis of the Financial and Social Obligations Imposed on Sectional Owners in Sectional Title Schemes, as Well as Their Enforcement' (LLD Thesis, Stellenbosch University) 20141.

95 of 1986.

8 of 2011 .

S 2(1) of the STSMA.

$S$ 2(2) of the STSMA.

S 2(7) of the STSMA.

S 2(7)(a)-(e) of the STSMA. 
are the units they own within the sectional titles scheme. Under these circumstances, the most suitable method of recovering payment "may be" to use insolvency law remedies to recover arrear levies, which would make the body corporate the defaulting owner's creditor.

In this article, we evaluate whether there is justification for treating trustees of the estates of insolvent members of bodies corporate differently from those who are liquidating properties of owners indebted to municipalities. The authors assess the differences between the statutory preference for payment of debts to municipalities, provided by section 118 of the Local Government: Municipal Systems Act ${ }^{9}$ (LGMSA), and the provisions of section $15(\mathrm{~B})(3)(\mathrm{a})(\mathrm{i})(\mathrm{aa})$ of the STA regarding debt collection by bodies corporate during insolvency proceedings. In particular, with reference to some of the decisions of the SCA, we evaluate whether these sections are differently subjected to section 89(1) of the Insolvency Act, and if so, the impact of such differentiation. The purpose of this article is to highlight that the manner in which the law is currently applied seems to provide some relief to trustees of estates where owners of properties owe certain charges and fees to municipalities when their estates are sequestrated (by barring them from paying historical debts), whereas the same advantage is not offered to trustees who are dealing with the insolvent estates of owners of section titles scheme units. It is argued that this amounts to unfair discrimination and is legally unsound.

This article is structured as follows: under heading 2, the duties of bodies corporate and owners within sectional titles schemes are discussed. Circumstances that can lead bodies corporate to decide to sequestrate the estates of some of their members are explored. Heading 3 discusses the general special preferences provided by legislation to municipalities and bodies corporate to assist them to collect what is owed to them when properties are sold. Here, the importance of the common-law principle of concursus creditorum is underscored. Heading 4 examines the differential statutory treatment of municipalities and bodies corporate in light of section 89 of the Insolvency Act when they collect amounts that are due to them during insolvency proceedings. Throughout the article, recommendations for law reform are made.

\section{PARTIES' FUNCTIONS AND DUTIES}

Sectional titles were introduced primarily to facilitate the provision of urgently needed residential accommodation within commuting distance from urban centres. ${ }^{10}$ Communal living in the form of sectional title ownership creates dependency between owners of different units and has proved attractive to many middle-class people. Factors such as perceived affordability, safety, lifestyle benefits, and shared costs of maintenance and upkeep of the complex are often cited as reasons people prefer to purchase property subject to sectional title. It is worth noting that in communal living, unit owners' autonomy in relation to the use of their property can be limited and

932 of 2000.

10 Van der Merwe "Many Faces of Sectional Title: A Comparative Survey of the Inadequate Legal Treatment of Non-Residential Sectional Title Schemes" 2016 TSAR 428. 
requires consideration of other unit owners. ${ }^{11}$ To ensure harmonious communal living, sectional title units are arranged so as to ensure preservation of the physical integrity and appearance of the common property, given that individual units are physically interdependent, and residents are seldom completely homogenous. ${ }^{12}$

The governance of sectional titles schemes is entrusted to the bodies corporate, which are responsible for the running and administration of the common property through appointed trustees. Among others, bodies corporate are required to establish a fund for administrative expenses relating to the repair and maintenance of the common property. ${ }^{13}$ Section $3(1)(c)$ of the STSMA empowers bodies corporate to require owners to make contributions necessary to defray the costs of rates and taxes, insurance and maintenance of these schemes, and electricity and water. These levies are in proportion to the quotas of owners' respective sections. All owners of properties that are subject to sectional title have an obligation to make contributions in the form of regular payment of levies in order to ensure the successful management of the complex or development. Failure to make such payments unfairly prejudices other unit owners within a complex or development because the financial burden regarding the management of the property is not evenly distributed.

It is also important for sectional title owners to participate in meetings relating to their schemes and to elect competent trustees who will manage their schemes efficiently. In order to effectively administer and manage these schemes, bodies corporate must "[d]o all things reasonably necessary for the enforcement of the rules and for the management and administration of the common property", ${ }^{14}$ including instituting civil action to recover arrear levies. Non-payment of sectional title levies negatively affects the proper administration and management of sectional title schemes. This results in bodies corporate experiencing shortfalls in their expected income, thereby preventing them from collecting sufficient funds to meet their financial obligations. ${ }^{15}$

Should bodies corporate not receive levies due by defaulting owners, the entire scheme will experience financial difficulties, thus placing a heavy burden on those owners whose payments are up to date. If defaulting owners have the means to pay or sufficient movable property that can be sold to satisfy their arrear levies, it may be worthwhile for bodies corporate to

11 See Boyce and Van der Merwe "The Rationale for the Imposition of Non-Financial Obligation on Apartment Owners in a Sectional Title Scheme" 2015 Stell LR 168 and Van der Merwe "The Adoption of the Institution of Apartment Ownership to Civilian Property Law Structures in the Mixed Jurisdiction of South Africa, Sri Lanka and Louisiana" 200819 Stell $L R 311$.

12 Van der Merwe and Erasmus "The Enforcement of the Obligation of Sectional Owner in a Sectional Title Scheme” 1999 THRHR 260.

$13 \mathrm{~S} 2$ of the STA.

$14 \mathrm{~S} 4(i)$ of the STSMA.

15 Maree ("Demanding Your Interest: A New Era for Sectional Titles" 2017 (Mar) De Rebus 26) correctly argues that the "[f]inancial pressures experienced by the debtor could similarly be endured by his co-owners who nevertheless pay their levies regularly". 
approach the Community Scheme Ombud for assistance. ${ }^{16}$ In terms of section $39(1)(e)$ of the Community Schemes Ombud Service Act, ${ }^{17}$ the body corporate may make an application to the Community Schemes Ombud Service for an order directing the defaulting owner to make payment of a contribution or any other amount due in terms of the registered rules of the sectional titles scheme. ${ }^{18}$ It is not mandatory to refer payment disputes to the Community Schemes Ombud Service. Bodies corporate may also use civil proceedings to recover arrear levies against defaulting owners by issuing summonses in courts of law..$^{19}$ It was confirmed in Body Corporate of Via Quinta $v$ Van der Westhuizen N.O., that the "[b]ody corporate has a discretion to either enforce payment of levies or contributions through the Ombud, or in terms of its common law right in any court of law against a defaulting owner for the recovery of arrear levies". 20 The effectiveness of using either the Ombud or courts depends on whether defaulting owners, after these processes have been concluded, will be able to pay arrear levies. If not, the most likely method of securing such payment "might" be to use the insolvency law remedy of sequestration. Decided cases seem to suggest that bodies corporate are more likely to institute sequestration and liquidation proceedings than municipalities; hence, the authors chose to deal only with bodies corporate in this section. However, this does not mean that municipalities, if there is a need to, cannot institute such proceedings.

\section{STATUTORY PREFERENCE FOR PAYMENT}

\section{Concursus creditorum}

If it is clear that the only asset of value that the defaulting owner owns is the unit within the sectional titles scheme, it might be worthwhile for the body corporate to apply for the sequestration of the owner's estate in order to recover arrear levies. ${ }^{21}$ In this regard, the body corporate must institute sequestration proceedings against the defaulting owner in the form of

16 In terms of $\mathrm{s} 39(1)(e)$ of the Community Schemes Ombud Act 9 of 2011, an applicant can bring an application for an order for the payment or re-payment of a contribution or any other amount.

179 of 2011.

18 In terms of Reg 19(1) of the Regulations on the Community Schemes Ombud Service, GN R1233 in GG 40335 of 2016-10-7, "[a]n application referred to in section 38(1) of the Act must be made by submission of an application by physical delivery or electronically, in accordance with the practice directive issued by the chief Ombud"'.

$19 S 38(d)$ of the Community Schemes Ombud Service Act clearly provides that "[a]ny person may make an application if such person is a party to or affected materially by a dispute". See also s 42 of this Act, which stipulates that "[a]n Ombud must reject an application by written notice to the applicant if the Ombud is satisfied that the dispute should be dealt with in a court of law or other tribunal of competent jurisdiction".

20 (A196/2017) [2017] ZAFSHC 215 par 15.

21 See Estate Logie $v$ Priest AD 312 319, where it was held: "It appears to me that it is perfectly legitimate for a creditor to take insolvency proceedings against a debtor for the purpose of obtaining payment of his debt. In truth that is the motive by which persons, as a rule are actuated in claiming sequestration orders. They are not influenced by altruistic considerations or regards for the benefit of other creditors, who are able to look after themselves. What they want is payment of their debt, or as much of it as they can get." 
compulsory sequestration. Section 9(1) of the Insolvency Act ${ }^{22}$ empowers any person who is owed an amount of R100.00 or more to apply for the sequestration of any person who is either insolvent or has conducted themselves in a manner that indicates that they may be insolvent. ${ }^{23}$ In terms of section 12 of the Insolvency Act, in order to succeed with this application, the body corporate must satisfy the court that the defaulting owner is in arrears with levies in an amount of R100.00 or more, that the defaulting owner has either committed an act of insolvency or is actually insolvent, and that there is reason to believe that the sequestration of the defaulting owner's estate will be to the advantage of the collective body of creditors. ${ }^{24}$ If these requirements are met, the provisional order that had been granted against the defaulting unit owner will be confirmed.

In South Africa, bodies corporate have attempted to use insolvency procedures hoping for the outcome that they would normally get when claiming payment of arrear levies through normal civil proceedings. For instance, in Body Corporate of Empire Gardens $v$ Sithole, ${ }^{25}$ the body corporate argued that it did not have an obligation to illustrate that there was a pecuniary benefit because it enjoyed certain preferences over other creditors. ${ }^{26}$ The body corporate urged the SCA "[t]o deviate from the trite principle of concursus creditorum and conclude that it is not necessary for bodies corporate to prove actual or prospective pecuniary benefit to the general body of creditors". ${ }^{27}$ The essence of this argument was that when bodies corporate act as sequestrating creditors, they are not required to comply fully with section 12(1) of the Insolvency Act, in that they should not have to satisfy the court that sequestration of defaulting owners will be to the advantage of the entire body of creditors. The body corporate took the approach that it would normally take when issuing a summons in a civil court - namely, that the order that the court will grant against the defaulting member will be to its sole advantage without regard to other creditors. In dismissing the body corporate's argument, the SCA held:

"The purpose and effect of the sequestration order is to "bring about a convergence of the claims in an insolvent estate to ensure that it is wound up in an orderly fashion and that the creditors are treated equally'. It cannot fittingly be described as a mechanism to be utilized by a creditor to claim a debt due by the debtor to one single creditor. Once a sequestration order is

$22 \quad 24$ of 1936

23 See s 8 of the Insolvency Act 24 of 1936. For a detailed discussion of acts of insolvency see Bertelsmann, Calitz, Evans, Harris and Louw Mars: The Law of Insolvency in South Africa 10ed (2019) 88-110.

24 See Body Corporate of Calswald Crest v Mbatha (94948/2015) [2019] ZAGPPHC 39 par 16. See also Braithwaite $v$ Gilbert 19844 SA 171 (N) 718, where it was held that "[t]he onus of satisfying the Court on these three points is on the creditor and there is no onus on the debtor to disprove any of them. Furthermore, the degree of proof required when application is made for a final order of sequestration is higher than that for the grant of a provisional sequestration order".

252017 (4) SA 161 (SCA)

26 Body Corporate of Empire Gardens v Sithole 2017 (4) SA 161 (SCA) par 6. In support of this contention, the court quoted Collett v Priest 1931 AD 290 299; Investec Bank Ltd v Mutemeri 2010 (1) SA 265 (GSJ) 274-275 and Meskin Insolvency Law and its Operation in Winding Up (2016) 2-1 par 2.1.

27 Body Corporate of Empire Gardens v Sithole supra par 11. 
made, a concursus creditorum comes into being. This means that the rights of the creditors as a group are preferred to the rights of the individual creditor."28

The court was emphasising that, under insolvency law, the court should not be blinded by the identity or nature of a creditor. The court when exercising its discretion to grant a sequestration order should be geared towards evaluating whether all the debtor's creditors would derive some financial advantage. ${ }^{29}$ The SCA further held that the principle of concursus creditorum "[m]eans that there should be a reasonable prospect of some pecuniary benefit to the general body of creditors as a whole". The SCA made it clear that the challenges that confront bodies corporate in relation to collecting levies are not novel, and do not warrant the immunity that is sought, as this would amount to courts usurping the function of the legislature. ${ }^{30}$ Thus, when bodies corporate decide to initiate sequestration proceedings against their defaulting members, they must fully comply with both the common-law and statutory requirements provided for in section 12(1) of the Insolvency Act. It clarified that bodies corporate who are creditors of their defaulting members are not exempted from the common-law principle of concursus creditorum in insolvency proceedings, in that they do not hold a special position and must be part of the general body of creditors whose claims must be dealt with in accordance with insolvency-law ranking of creditors. Thus, the idea is to serve the full body of all creditors, and not the creditor that brought the application for sequestration forward or that has a claim tied in with some sentimental values relating to the nature of the work in which such creditor is engaged.

\section{General statutory preference for payment}

In order to understand the position of bodies corporate when they have instituted sequestration proceedings against their members, it is important to start by assessing whether they enjoy the same position as municipalities in relation to the statutory hypothecs that enable municipalities to insist on payment of certain charges and fees before properties within their jurisdiction can be transferred to new owners. Section 118 of the LGMSA plays a fundamental role in first assisting municipalities to collect all debts that are due to them when defaulting owners seek to transfer their properties. ${ }^{31}$ Secondly, it appears to be conferring some form of priority

28 Body Corporate of Empire Gardens $v$ Sithole supra par 9.

29 See Marumoagae and Mokgoetsi "The Need to Clarify the Sheriff's Duties When Executing Writs of Execution That Could Indicate the Debtor's Insolvency" 201931 SA Merc LJ 302.

30 Body Corporate of Empire Gardens v Sithole supra par 12.

31 See Johannesburg Municipality v Cohen's Trustees 1909 TS 811817, where Innes JA, commenting on the LGMSA's predecessor held that "[n]ow reading that section in connection with other provisions of the statute, the intention seems to have been to give to the local authority a right to veto the transfer of property until its claims in respect of rates should be satisfied. The result, of course, was to create, in effect, a very real and extensive preference over the proceeds of rateable property realised in insolvency; and to compel payment of the burden thus imposed before a sale of such property could be carried through, even in cases where insolvency had not supervened". See also Rabie NO $v$ Rand Townships Registrar 1926 TPD 286, where it was held that "[b]ut is it clear from the fact that the privilege of preventing transfer is given to municipal councils that this right constitutes a claim ranking in priority to other debts? These words ordinarily convey the idea of a right in 
during insolvency proceedings that enable municipalities to be paid what is owed to them before transfers can be effected. This payment is made before secured creditors are paid in respect of properties that trustees wish to transfer to new owners. Since the promulgation of the LGMSA, South African courts have attempted to clarify what section 118 entails in relation to the right of municipalities. In terms of section 118(1)(b) of the LGMSA, a registrar of deeds is not allowed to register a transfer of property before a prescribed certificate issued by the municipality that has jurisdiction over the area where the property is situated has been provided. ${ }^{32}$ This certificate must certify that the seller has paid all "[m]unicipal service fees, ${ }^{33}$ surcharges on fees, property rates and other municipal taxes, levies and duties during the two years preceding the date of application for the certificate". ${ }^{34}$ In order for municipalities to issue clearance certificates, only portions of debts owed in respect of properties that are sought to be transferred for a period of two years before applications for clearance certificates are payable to municipalities. ${ }^{35}$ This provision effectively restricts transfers of properties until municipalities have been paid all debts that arose in the two years before the date on which they are required to issue clearance certificates. ${ }^{36}$ These are various debts that were accumulated and became payable at different times within the preceding two years before the municipality concerned was requested to issue a clearance certificate. ${ }^{37}$

the person holding such claim to have the property sold which is subject to the claim and to be paid first out of the proceeds, or a right, when the property is sold in execution by another creditor, to be so paid and not merely a right to resist any dealing with the property unless the claim is paid".

32 See Sheriff, Johannesburg North v Yellow Dot Property Investments 2016 (5) SA 107 (GJ) par 17, where it was stated that "[i]n terms of $s 118$ of the Municipal Systems Act, the Registrar of Deeds may not register the transfer of the property except on production of the rates clearance certificate confirming that all amounts due to the municipality in respect of the above services for the two years preceding the application had been paid". See also Tshwane City v Mitchell 2016 (3) SA 231 (SCA) par 3 and City of Johannesburg v Even Grand 6 CC 2009 (2) SA 111 (SCA) par 14, where it was held that "[s]ection 118(1) of the Systems Act gives the appellant the right to veto the transfer of property until such time as the rates and other amounts due in respect of the period of two years preceding the date of application for the certificate have been fully paid". See further Nelson Mandela Bay Municipality v Amber Mountain Investments 3 (Pty) Ltd 2017 (4) SA 272 (SCA) par 26, where it was held that "[t]he clear intention of the legislature was to limit the period in $\mathrm{s} 118(1)$ to two years preceding the date of application for the certificate".

33 In Geyser v Msunduzi Municipality 2003 (5) SA 18 (N) 34, it was held that "[i]t is clear from the language employed in $\mathrm{s} 118$ of the Act that the words 'municipal service fees' include the charges for electricity and water supplied by first respondent to the occupier of a property". The Constitutional Court, in Mkontwana $v$ Nelson Mandela Metropolitan Municipality; Bissett $v$ Buffalo City; Transfer Rights Action Campaign v MEC, Local Government and Housing, Gauteng, (Kwazulu-Natal law Society and Msunduzi Municipality as amici curiae) 2005 (1) SA 530 (CC) par 54, held that the section "118(1) certificate must also cover the consumption charges due in connection with the property by an occupier who holds over unlawfully after the termination of a lease or some other legal relationship that rendered occupation lawful at the time it began. Here again, the relationship between the consumption charge and the property as well as the owner are sufficiently strong for the owner to bear the risk".

$34 \mathrm{~S} 118(1)(b)$ of the LGMSA.

35 Tshwane City $v$ Uniqon Wonings (Pty) Ltd 2016 (2) SA 247 (SCA).

36 Jordaan v Tshwane Metropolitan Municipality 2017 (6) SA 287 (CC) par 55.

37 BOE Bank Ltd v City of Tshwane Metropolitan Municipality 2005 (4) SA 336 (SCA) par 10. 
In terms of section 118(3) of the LGMSA, an amount of the fees and charges stated in section 118(2) of this Act enjoy "[p]reference over any mortgage bond registered against the property". ${ }^{38}$ This provision neither uses the phrase "all amounts" nor prescribes any time limits in which amounts stated herein ought to have been due. This provision "[d]oes not refer to a category or class of debts but to the aggregate of different debts secured by a single charge or hypothec". ${ }^{39}$ In BOE Bank Ltd $v$ City of Tshwane Metropolitan Municipality, ${ }^{40}$ it was authoritatively held that section $118(3)$ of the LGMSA is not subject to the time limit that is prescribed in section 118(1) of this Act. ${ }^{41}$ The SCA held that "[f]or purposes of $s 118(3)$ it therefore does not matter when the component parts of the secured debt became due. The amounts of all debts arising from the stipulated causes are added up to become one composite amount secured by a single hypothec which ranks above all mortgage bonds over the property". ${ }^{42}$ Section 118(3) of the LGMSA can be relied upon by municipalities to insist on payment of charges and fees that became due before the period stipulated in section $118(1)$ of this Act. It was held in City of Johannesburg $v$ Kaplan NO,43 that section 118(3) of the LGMSA creates security for payment in favour of municipalities of the prescribed municipal debts in respect of which municipalities enjoy preference over secured creditors on the proceeds of the properties sought to be transferred. The SCA held that municipalities have an obligation to issue clearance certificates once all amounts that are due in relation to properties in question during the two years immediately before the application for such certificates were made..$^{44}$

It is evident that section 118(3) of the LGMSA in particular creates "[a] statutory hypothec over the property and, significantly, [one] that is in preference to any mortgage bond". ${ }^{45}$ Heher JA, in City of Johannesburg $v$ Kaplan NO,46 remarked that there is a tendency in South Africa for the creation of statutory quasi-liens and statutory charges or preferences. The question then is, does the "statutory hypothec" that has been created in favour of municipalities in relation to payment of outstanding municipal charges also extend to bodies corporate regarding outstanding levies when their members have sold their properties and wish to transfer ownership to new owners? The answer to this question appears to be in section $15 \mathrm{~B}(3)(\mathrm{a})(\mathrm{i})(\mathrm{aa})$ of the STA. This section provides:

38 See City of Tshwane Metropolitan Municipality v Mathabathe 2013 (4) SA 319 (SCA) par 10 , where the court held that the effect of s 118(3) of the LGMSA "[i]s to create in favour of a municipality a security for the payment of the prescribed municipal debts so that a municipality enjoys preference over a registered mortgage bond on the proceeds of the property".

39 BOE Bank Ltd $v$ City of Tshwane Metropolitan Municipality supra par 10.

40 Supra.

41 Ibid.

42 BOE Bank Ltd v City of Tshwane Metropolitan Municipality supra par 11, where the court further held that "[c]onversely, if the Legislature really intended to render $s 118(3)$ subject to the same two-year time limit contemplated in s 118(1), it could have done so in a number of ways".

432006 (5) SA 10 (SCA) par 16.

44 City of Cape Town v Real People Housing (Pty) Ltd 2010 (5) SA 196 (SCA) par 13 and 14.

45 Hoofar Investments (Pty) Ltd v Moodley 2009 (6) SA 556 (KZP) par 15.

46 Supra par 20. 
"The registrar shall not register a transfer of a unit or of an undivided share therein, unless there is produced to him a conveyancer's certificate confirming that as at date of registration if a body corporate is deemed to be established in terms of section 2(1) of the Sectional Titles Schemes Management Act, that body corporate has certified that all moneys due to the body corporate by the transferor in respect of the said unit have been paid, or that provision has been made to the satisfaction of the body corporate for the payment thereof."

Section 118(1) of the LGMSA states that "[a] registrar of deeds may not register" the transfer of property unless the conditions in that provision have been complied with. It is trite that the use of the word "may" denotes the discretion of the person with authority to perform a particular function. It is interesting to note that unlike this provision, section $15 \mathrm{~B}(3)(\mathrm{a})(\mathrm{i})(\mathrm{aa})$ of the STA provides that "[t]he registrar shall not register" the transfer of property unless a conveyancer's certificate confirming that the body corporate has been paid what the member who wishes to register transfer of property owes to the body corporate. The usage of the phrase "shall not" appears to indicate that the Registrar of Deeds in terms of $15 \mathrm{~B}(3)(\mathrm{a})(\mathrm{i})(\mathrm{aa})$ of the STA does not have a discretion to decide to register the transfer of property if there are amounts owing to the body corporate, irrespective of when such amounts were due. Unlike section 118(1) of the LGMSA, the legislature in section $15 \mathrm{~B}(3)(\mathrm{a})(\mathrm{i})(\mathrm{aa})$ of the STA did not provide a time period within which debts owed to the body corporate must have fallen due in order for the body corporate to decline to issue the conveyancer's certificate.

While it is clear from section 15B(3)(a)(i)(aa) of the STA that there is some form of statutory preference if a property is to be sold, the position of bodies corporate is nonetheless not entirely clear in the event of the insolvency of their members, when properties in question are subjected to the rights of mortgage bondholders. In an attempt to clear the confusion, Brand $\mathrm{J}$ in $\mathrm{Nel}$ NO $v$ Body Corporate of the Seaways Building, ${ }^{47}$ held that the preference (if any) that is accorded by section $15 \mathrm{~B}(3)(\mathrm{a})(\mathrm{i})(\mathrm{aa})$ of the STA to bodies corporate in respect of arrear levies during sequestration proceedings can be said to be created by section 89(1) of the Insolvency Act as part of the costs of realisation. In the following section, the authors evaluate whether the position of municipalities and bodies corporate is the same where they are requested to provide clearance certificates when they are owed charges, fees and levies.

\section{SEQUESTRATION OF DEFAULTING OWNERS}

The issuing of clearance certificates becomes more complex when municipalities are faced with applications relating to properties that are not only subject to security, but also involve the estates of owners who are either sequestrated or liquidated. While section 118(3) of the LGMSA is an independent and self-contained remedy, ${ }^{48}$ it is nonetheless subject to section 118(2) of the LGMSA in insolvency proceedings, which provides that "[i]n case of the transfer of property by a trustee of an insolvent estate, the

471995 (1) SA 130 (C) 136.

48 Steve Tshwete Local Municipality v Fedbond Participation Mortgage Bond Managers (Pty) Ltd 2013 (3) SA 611 (SCA) par 12. 
provisions of this section are subject to section 89 of the Insolvency Act". This entails that once a sequestration or liquidation order has been granted by the court and all creditors have convened a meeting to elect a trustee who will be appointed by the Master of the High Court, where it is clear that the municipality has a claim in terms of the fees and charges listed in both subsections (1) and (3) of section 118 of the LGMSA, the trustee must deal with the municipality's claim in terms of section 89 of the Insolvency Act.

In relation to claims for clearance certificates that are made by trustees and liquidators, section 89 of the Insolvency Act is, to a large extent, aimed at diluting the strong position that section 118(1) and (3) of the LGMSA provide to municipalities. In terms of section 89(4) of the Insolvency Act:

"Notwithstanding, the provisions of any law which prohibits the transfer of any immovable property unless any tax defined in subsection (5) due thereon has been paid, that law shall not debar the trustee of an insolvent estate from transferring any immovable property in that estate for the purpose of liquidating the estate, if he has paid the tax which may have been due on that property in respect of the periods mentioned in subsection (1) and no preference shall be accorded to any claim for such a tax in respect of any other period."

This provision makes it absolutely clear that section 89 of the Insolvency Act overrides provisions restricting transfer of immovable properties because of outstanding monies that are due to the State, provincial administration, municipality or a body established by statute (such as a body corporate) that is mandated to collect periodic payments incidental to the ownership of immovable properties. ${ }^{49}$ Most importantly, section $89(1)$ of the Insolvency Act provides a time period that is different from that provided in section 118 (1) of the LGMSA with regard to the date from which the amount owed to the State, municipality, provincial administration and bodies corporate must be calculated in order to allow the trustee to receive the necessary clearance from these authorities in order to transfer property. Section 89(1) of the Insolvency Act provides two periods within which the amounts due to these authorities must be calculated. The first period is a period of two years or less from the date on which the court grants a sequestration order. The second period is calculated from the date of the sequestration order to the date of transfer of the property. In other words, for the purposes of receiving clearance documents confirming required payments, the trustee is only obliged to pay arrear charges, fees and "levies" owed to the identified authorities if these became due in the two years before the date of sequestration or after sequestration but before the date of transfer. These authorities are legislatively prohibited from asking for any payment that became due in respect of the property subject to sequestration or liquidation proceedings outside this period. Once the trustee has made the necessary payment, these authorities are legislatively obliged to issue the necessary documents to enable the trustee to transfer the property.

The two periods provided for in section 118(1) of the LGMSA or any other period provided for in any other legislation will not be affected by section 89(4) of the Insolvency Act as long as it is within the period starting two years preceding the date of sequestration order and ending on the date of

$49 \mathrm{~S} 89(5)$ of the Insolvency Act. 
transfer of property. In City of Johannesburg $v$ Kaplan NO,50 the SCA held that "[w] hen ... the embargo provision in any other law is effectively longer than that in $s 89(1)$, then, by reason of the provisions of $s 89(4)$, the period in s 89(1) will override the period in the other law". In insolvency proceedings, the preference enjoyed by authorities such as municipalities and "bodies corporate" 51 over secured creditors and payment of amounts owing to them is restricted to the period identified in section 89(4) of the Insolvency Act. These authorities, which have a legislative mandate to collect charges, fees and levies in respect of immovable properties, are legislatively prevented from frustrating trustees and liquidators by declining to provide the necessary clearance certificates that would enable transfers of immovable properties by demanding payment of historical debts over such properties that were not due as provided for in section 89(4) of the Insolvency Act.

It is interesting to note that while section 118(1) of the LGMSA provides that municipalities have preference over charges and fees that were due within a period of two years before the date of the application of the clearance certificates, nonetheless, section $15 \mathrm{~B}(3)(\mathrm{a})(\mathrm{i})(\mathrm{aa})$ of the STA does not prescribe any time period. Unlike section 118(2) of the LGMSA, section $15 \mathrm{~B}(3)(a)(i)(a a)$ of the STA does not make any reference to the insolvency of owners of units within sectional titles schemes and how bodies corporate should deal with them when their estates are either sequestrated or liquidated. Nonetheless, the SCA, in Nel NO v Body Corporate of the Seaways Building, ${ }^{52}$ held that "[a]s a matter of language, and particularly also in the light of the legislative history of the provision, the conclusion is ineluctable that the Legislature intended the provision to apply whether or not the transferor was insolvent".

Even though the SCA appears to be of the view that section $15 \mathrm{~B}(3)(\mathrm{a})(\mathrm{i})(\mathrm{aa})$ of the STA also covers insolvency proceedings, it is not entirely clear to what extent this provision is subject to section 89 of the Insolvency Act. Unlike section 118(2) of the LGMSA, section 15B(3) of the STA does not have a provision that expressly subjects this provision to section 89 of the Insolvency Act. The drafting difference between these two sections opens up an unfortunate debate relating to the extent to which section $15 \mathrm{~B}(3)(\mathrm{a})(\mathrm{i})(\mathrm{aa})$ of the STA is subject to the time frames that are meant to assist trustees and liquidators of estates of insolvent owners of units within sectional titles.

In an important judgment, Barnard NO $v$ Regspersoon van Aminie, ${ }^{53}$ (unfortunately written in Afrikaans from the authors' perspective), it appears from the editor's summary that the SCA in this judgment held that "contributions" due by unit owners cannot be regarded as taxes as provided for in section 89(5) of the Insolvency Act. Thus, the time period prescribed in

Supra par 24.

51 As is shown below, the SCA appears to be of the view that this provision does not include bodies corporate.

521996 (1) SA 131 (SCA) par 11.

532001 (3) SA 973 (SCA). Given that this judgment is written in Afrikaans (in which the authors are not proficient), the authors relied exclusively on the editor's summary. The editor used the word "contributions" and in the context of the discussion, this appears to mean "levies". 
section 89(1) of the Insolvency Act is not applicable to assist trustees and liquidators of estates of owners of units within sectional titles schemes. This effectively means that bodies corporate are placed in a better position than municipalities and can require payment of all the outstanding levies irrespective of when they were due when trustees and liquidators request clearance certificates. ${ }^{54}$ It appears as if this is also how Bertelsmann et al understood this case. These authors' state:

"In the past it was uncertain as to whether or not the contributions payable to a body corporate could be regarded as 'tax' for the purposes of $s 89(1)$, (4) and (5) or whether these contributions formed part of the costs of realisation as provided for in s 89(1) of the Insolvency Act. In Barnard NO v Regspersoon van Aminie, the Supreme Court of Appeal brought an end to the uncertainty and found that arrear contributions were not taxes for the purposes of $s$ 89(1) (4) and (5) of the Insolvency Act, because they were not paid to the State or a government institution, and therefore the two-year limitation contained in those subsections could not be applied to the arrear contributions." 55

It is submitted that if indeed this is what the court said in Afrikaans in this judgment, it cannot be doubted from the reading of section 89 in its entirety that what the court is said to have said is clearly incorrect. ${ }^{56}$ In fact, to the extent that the court expressed itself in these terms, this is a clear misrepresentation of section 89(5) of the Insolvency Act in particular. This provision does not restrict the institutions to which payment should be made only to the State and a governmental institution, as the court is alleged to have said. A proper reading of section 89 indicates that the institutions identified in section 89(5) of the Insolvency Act are: 1) the State; 2) a provincial administration; and 3) a body established by or under the authority of any law in discharge of a liability to make such periodic payments, if that liability is incidental to ownership of that property. The reach of section 89(5) of the Insolvency Act is broader than what the SCA is alleged to have stated in Barnard NO v Regspersoon van Aminie. First, it is beyond contention that this provision covers municipalities, which are not expressly referred to in the provision. Secondly, it is difficult to understand how bodies corporate can be excluded from the ambit of this provision given that they are established in terms of the STA and operate in terms of the STSMA; these are national laws as provided for in this provision.

Assuming that by the word "contribution" the SCA meant levies, it is submitted that the SCA erred in concluding that contributions do not constitute part of the word "tax" for the purposes of section 89 of the Insolvency Act. If indeed the reasoning of the court was limited to the view that contributions cannot be regarded as "tax" for the purposes of section 89(5) (because institutions that should be able to demand arrear "tax" in terms of this provision are the State or a governmental institution, which bodies corporate are not), this represents a total misreading of the provision. This conclusion also amounts to a clear disregard of the definition of the word "tax" in section 89(5) of the Insolvency Act, which provides that it means, in relation to immovable property, "[a]ny amount payable periodically

54 Bertelsmann et al Mars: The Law of Insolvency 549.

55 Ibid.

56 The authors use the language of reporting because they could not directly read and comment on what the court said due to their lack of proficiency in Afrikaans. 
in respect of that property to the State or for the benefit of a provincial administration or to a body established by or under the authority of any law." It is common cause in practice that, just like municipalities, bodies corporate are expected to collect monthly levies from their members in order to properly administer sectional titles. Monthly payments are indeed periodic payments and meet the definition of the word "tax".

There was no need for the SCA to take a technically complex view of what the word "tax" entails. The word "tax" is generally understood as involuntary and compulsory fees that must be paid to a recognised authority, nonpayment of which attracts a particular sanction. In fact, this can be defined as "a sum of money demanded by government for its support or for specific facilities or service, levied upon incomes, property, sales etc". ${ }^{57}$ While the word "tax" is generally understood in terms of state revenue collection, nonetheless, the State in terms of section 89(5) of the Insolvency Act expressly includes, in the definition of this word, institutions such as bodies corporate because they are also legislatively empowered to collect periodic amounts from owners of units of the sectional titles scheme that they are operating. For these reasons, it is submitted that the conclusion of the SCA in Barnard NO $v$ Regspersoon van Aminie, insofar as it excluded bodies corporate from the ambit of section 89(5) of the Insolvency Act, should be rejected. One can hope that when either the SCA or the Constitutional Court is called upon to adjudicate a dispute dealing with the status of bodies corporate in relation to this provision, they will properly interpret the law by recognising bodies corporate as being fully included within the ambit of section 89 of the Insolvency Act.

It appears that the SCA decision in Barnard NO $v$ Regspersoon van Aminie has received academic endorsement. According to Bertalsmann et $a l$, the effect of section $15 \mathrm{~B}(3)(\mathrm{a})(\mathrm{i})(\mathrm{aa})$ of the STA is that "[w]here a sectional title unit owner is insolvent, the body corporate may refuse to issue a clearance certificate unless all the outstanding levies and other moneys due to the body corporate have also been paid in full". ${ }^{58}$ It is submitted that a proper reading of section 89(5) of the Insolvency Act does not support this conclusion. In fact, bodies corporate are indeed subject to the entire section 89 of the Insolvency Act and the time period that is prescribed for payment of taxes. As such, there is no justification for trustees of the estates of owners of units within sectional titles being burdened with payment of historical debts before they can be provided with clearance certificates, whereas trustees and liquidators of the estates of property owners who owe municipalities are protected against such.

It is submitted that if it is accepted that bodies corporate enjoy preference over arrear levies when their members are sequestrated and that such levies can be claimed as part of costs of realisation as provided for in section $89(1)$, then it cannot be that they are excluded from the time period provided for in section 89(4) of the Insolvency Act, which also covers periodic arrear charges and fees that are payable to municipalities. The SCA in Body Corporate of Empire Gardens v Sithole, ${ }^{59}$ without engaging the conundrum

Dictionary.com https://www.dictionary.com/browse/tax (accessed 2020-02-25).

58 Bertelsmann et al Mars: The Law of Insolvency 549.

59 Supra. 
of whether contributions collected by bodies corporate fell to be interpreted as taxes (for the purposes of trustees who require clearance certificates to transfer properties out of sequestrated estates), stated that "[i]n terms of section 89(1) of the Insolvency Act, outstanding levies due to the body corporate are treated as being part of the cost of realisation".

Section 15B(3)(a)(i)(aa) of the STA cannot be interpreted as providing bodies corporate with a stronger right than that enjoyed by municipalities when property owners' estates are either sequestrated or liquidated. It is respectfully further submitted that the SCA erred in Nel NO $v$ Body Corporate of the Seaways Building, ${ }^{60}$ when it held that "[t]he protection granted to a body corporate would be considerably more extensive than that accorded, for instance, to municipalities for rates"; and further that "[t]he body corporate will have a de facto preference for an unlimited period, subject only to the law of prescription. And the type of debt due by a transferor which is protected by the contested provision would be wider than that owing to a municipality for rates". ${ }^{61}$ The SCA did not provide jurisprudential reasoning as to why this provision should be read as providing more protection than that provided by section 118 of the LGMSA or even a sound justification as to why this could be said to be the legislature's intention.

The authors are of the view that the position outlined by SCA in Nel NO $v$ Body Corporate of the Seaways Building and Barnard NO v Regspersoon van Aminie cannot be sustained in a constitutional democracy. The SCA's conclusion and reasoning in these two cases leads to unjustifiable differential treatment of trustees (and by extension, of two types of property owner) on the basis of which kind of legislative "authority" is owed charges, fees and levies. Trustees who are seeking to transfer the immovable property of insolvent owners indebted to municipalities are only liable to pay arrear charges and fees from a period starting two years before the date of a sequestration or liquidation order. This means that the insolvent estates of sequestrated owners will not be subject to the payment of historical debt before municipalities can issue clearance certificates that are outside the boundary set by section 89(1) and (4) of the Insolvency Act.

However, the position is different for trustees who are liquidating estates of insolvent members of bodies corporate. These trustees do not enjoy the benefit of a restriction on payment obligations as provided for by section 89(1) and (4) of the Insolvency Act. This means that the estates of insolvent members of bodies corporate are effectively obliged to settle all debts due to the bodies corporate - that is, including historical debts beyond two years before the date of sequestration order provided by section 89(1) and (4) of the Insolvency Act. To date, neither the SCA nor any of the divisions of the High Court have evaluated the real impact of the law as it is currently applied. It is submitted that this is an infringement of section 9 of the Constitution of the Republic of South Africa, 1996 (Constitution) and cannot be justified under section 36 of this Constitution.

\footnotetext{
Supra par 140.

Ibid.
} 
The differentiation identified in this provision is not one of the grounds of discrimination listed in section 9(3) of the Constitution. ${ }^{62}$ To challenge this differentiation, any trustee of an insolvent estate of an owner in a sectional titles scheme (the owner) will shoulder the burden of establishing unfairness because this situation amounts to a differentiation on an analogous ground. Unfairness will be tested in line with the test of unfair discrimination established by the Constitutional Court in Harksen $v$ Lane NO.63 In terms of this test, a court starts by assessing whether the manner in which the law differentiates the position of trustees of insolvent estates (in relation to arrear charges, fees and levies), depending on whether they are requesting clearance certificates from municipalities or bodies corporate, amounts to discrimination. We are of the view that this amounts to discrimination because the law provides differently depending on whether the trustees of insolvent estates seeking to transfer property of insolvent owners are dealing with municipalities or with bodies corporate. The benefits accorded by section 89(4) of the Insolvency Act are only applicable to trustees who request clearance certificates from municipalities.

Once a court has identified any discrimination, it has to determine whether there is a rational connection between the discrimination and a legitimate governmental objective. ${ }^{64}$ It is submitted that there is no rational connection between this discrimination and any governmental purpose. In fact, it is doubtful that the legislature intended that there should be this disparity. We are therefore of the view that this amounts to unfair discrimination and that it is thus unconstitutional. In light of confusion created by the SCA, we are of the view that the legislature must step in and clarify its intention. First, we recommend that the legislature clarify whether it intended to provide different payment periods for trustees dealing with municipalities as opposed to those dealing with bodies corporate. If so, then they should provide some form of rational justification for such differential treatment. If not, they should ensure that trustees, irrespective of whether they are dealing with a municipality or a body corporate, are treated the same when they seek to transfer ownership of properties in the estates that they are liquidating in terms of section 89(1) of the Insolvency Act.

Secondly, we recommend the amendment of section $15 \mathrm{~B}(3)$ of the STA through the insertion of section $15 \mathrm{~B}(3)(a)(i)(c c)$ which should read: "in the case of a transfer of property by a trustee of an insolvent estate, the provisions of this section are subject to section 89 of the Insolvency Act", which is in line with section 118(2) of the LGMSA. This will erase any doubt about the extent to which $15 \mathrm{~B}(3)(a)$ (i) is subject to the Insolvency Act. It cannot be denied, as was stated by the SCA in Steve Tshwete Local Municipality $\vee$ Fedbond Participation Mortgage Bond Managers (Pty) Ltd, 65 that the words of section 89(4) of the Insolvency Act (where the legislature expressly provides that the trustee shall not be prevented by any law that prohibits transfer of property before payment is made to relevant authorities

62 See Prinsloo v Van der Linde 1997(4) SA 1 (CC) par 28-31 for an approach that courts employ in determining discrimination that is not based on any of the listed grounds.

631998 (1) SA 300 (CC) par 53.

64 Smith "Equality Constitutional Adjudication in South Africa" 201414 AHRLJ 609616.

65 Supra. 
like municipalities and bodies corporate) "[l]end themselves to the interpretation that the object of $\mathrm{s} 89$ was to provide a remedy to a trustee by limiting the impediment created by embargo provisions". ${ }^{66}$ The authors' recommendation is intended to extend the same privilege to trustees and liquidators of property of unit owners within sectional titles schemes.

\section{CONCLUSION}

It is commonly accepted that, in insolvency proceedings, the status of the creditor is of paramount importance. In this article, the conundrum faced by trustees of insolvent estates of owners of properties that are subject to sectional title is highlighted. In relation to acquiring clearance certificates, the authors have demonstrated that trustees dealing with bodies corporate are treated differently from trustees who are dealing with municipalities. The latter trustees enjoy the protection provided by section 89 of the Insolvency Act, which protection has been denied by the SCA to trustees who are dealing with bodies corporate when seeking to transfer properties of insolvent owners within a sectional titles scheme. We have argued that the legislature should intervene by making its intention clear as to whether it envisaged this disparity, or whether it intended the same treatment of trustees of insolvent estates irrespective of whether they are dealing with municipalities or bodies corporate.

66 Steve Tshwete Local Municipality v Fedbond Participation Mortgage Bond Managers (Pty) Ltd supra par 18. 